\title{
Predicting flowering of 130 plants at 8 locations with temperature and daylength
}

\author{
LARRY M. WHITE
}

Author is a range scientist USDA-ARS, Southern Plains Range Research Station, 2000-18th St., Woodward, Okla. 73801.

\begin{abstract}
An improved plant phenological method is needed to accurately predict flowering of a large array of plant species at locations with a wide range of latitude. Degree days or degree days times daylength cannot be used to accurately predict flowering of both early and late flowering species when grown at locations with wide range of latitude. Published flowering dates of 130 plant species from among 8 locations in central North America ranging in latitude from 39 to $50^{\circ} \mathrm{N}$ and longitude 84 to $108^{\circ} \mathrm{W}$ were used to develop a degree days times daylength factor to predict flowering dates. Plants flowering in late June flowered at the same time at all 8 locations regardless of latitude. Species flowering earlier than late June flowered earlier at southern locations than those at Treesbank, Manitoba. Species flowering after late June flowered later at southern locations than those at Treesbank. Flowering of 124 species divided among 8 locations was most accurately predicted by the accumulation of degree days (threshold $=2^{\circ} \mathrm{C}$ ) times daylength factor $(1 /(0.259$ $0.0140 *$ daylength) from the first of December. This method slightly discounts daylength below 13 hours and greatly increased its weight for every hour over 13 hours. This method predicted flowering dates with a standard deviation of $0.1,0.5,-1.7,2.4,-0.1,6.0,-1.8$, and -1.1 days for Swift Current, Saskatchewan; Treesbank, Manitoba; Sidney, Mont.; Fargo, N.D.; Sauk and Dane Co., Wisc.; Wauseon, Ohio; and Manhattan, Kans.; respectively. Degree days or degree days times daylength had a standard deviation of 10 and 18 days in predicting flowering dates at Manhattan, Kans.
\end{abstract}

Key Words: degree days, flowering, modeling, phenology

An improved plant phenological method is needed to accurately predict flowering date of a large array of plant species at locations with a wide range of latitudes. Hopkins' Law (Hopkins, 1938) states that "Other conditions being equal, the variation in the time of occurrence of a given periodical event in life activity in temperate North America is at the general average rate of 4 days to each 1 degree latitude, 5 degrees longitude, and 400 feet

This article is a contribution from USDA, Agricultural Research Service.

All programs and services of the USDA are offered on a nondiscriminatory basis without regard to race, color, national origin, religion, sex, age, marital status, or handicap.

Manuscript accepted 24 Jul. 1994.
(122 meters) of altitude, later northward, eastward, and upward in spring and early summer, and the reverse in late summer and autumn". Caprio (1967) and Hopp and Blair (1973) found that the flowering of lilac (Syringa vulgaris L. and S. persica X vulgaris L.) at various locations in western, north central and north eastern United States did not follow Hopkins' Law.

The summation of positive temperatures (degree days) above a threshold temperature has been used to predict flowering dates (Lindsey and Newman 1956, Holmes and Robertson 1959, White 1979). Degree days often failed when applied in climatic areas that differed significantly from the locations where it was developed (Holmes and Robertson 1959). Degree days was inadequate to predict plant development or flowering date when crops were planted at different dates (Madariaga and Knott 1951) and locations (Magoon and Culpepper 1932, Moorman et al. 1990).

Nuttonson (1955) found that degree days times daylength was better than degree days alone in predicting development of winter and spring wheat (Triticum aestivum L.) at a wide range of latitudes in the United States and Russia. McMaster and Smika (1988) and others have also shown this or conflicting results. Recent models of winter cereal development are based upon rate of daylength change at the time of crop emergence (Baker et al. 1980, McMaster et al. 1991). In contrast, development of spring cereals was based upon daylength (not rate of change) at crop emergence (Wright and Hughes 1987). Robertson (1953 and 1968) and Wright and Hughes (1987) found that the development of wheat and barley (Hordeum vulgare L.) responded to daylength above some threshold depending upon growth stage rather than the simple relationship proposed by Nuttonson (1955).

The objective of this study was to develop a method to predict flowering dates of a large array of plant species at 8 locations ranging from 39 to $50^{\circ} \mathrm{N}$ latitude and 84 to $108^{\circ} \mathrm{W}$ longitude in central North America. Degree days or degree days times daylength cannot be used in plant growth models to predict plant development or flowering dates of plants at locations with a wide range of latitude.

\section{Materials and Methods}

Published data from 8 locations (Swift Current, Saskatchewan $\left[50.27^{\circ} \mathrm{N} 107.73^{\circ} \mathrm{W}\right]$; Treesbank, Manitoba $\left[49.7^{\circ} \mathrm{N} 99.6^{\circ} \mathrm{W}\right]$; Sidney, Mont. [47.73 $\mathrm{N} 104.15^{\circ} \mathrm{W}$ ]; Fargo, N.D. [46.9 N $96.8^{\circ}$ W]; Sauk Co., Wisc. [43.6 N 89.67 W]; Dane Co., Wisc. [43.08 $\mathrm{N} 89.42^{\circ} \mathrm{W}$; Wauseon, Ohio [41.6 $6^{\circ} \mathrm{N} 84.12^{\circ} \mathrm{W}$; and Manhattan, Kans. [39.18 $\left.\mathrm{N} 96.57^{\circ} \mathrm{W}\right]$ ) were used to test the accuracy of various methods of predicting flowering dates for a 
wide array of plant species. Mean flowering dates of 145 plant species near Swift Current (Budd and Campbell 1959), 400 species near Treesbank (160 km southeast of Brandon) (Criddle 1927), 170 species near Fargo (Stevens 1956), and yearly flowering dates of 53 species near Sidney (White 1979), 233 species in Sauk and Dane counties near Madison, (Leopold and Jones 1947), 161 species near Wauseon (Smith 1915), and 132 species near Manhattan (Hulbert 1963) were sorted to identify those species common at Treesbank and at any one of the other 7 locations. After updating plant names there were 64 plant species common between Treesbank and Swift Current and 22, 39, 41, 30, 24, and 17 plant species common between Treesbank and Sidney, Fargo, Sauk, Dane, Wauseon, and Manhattan, respectively (Table 1). Data included 8 species of trees, 12 shrubs, and 110 forbs for a total of 130 plant species. The forbs included 88 perennial, 9 biennial, and 13 annual species. At Swift Current, Treesbank, and Fargo where data were not available for individual years a species was used only when the mean flowering date was based on 3 or more years of data. Where yearly flowering dates were available at Sidney, Sauk, Dane, Wauseon, and Manhattan only flowering dates within a given 5-year period were used and only if flowering had been recorded for at least 3 of the 5 years.

Budd and Campbell (1959) defined flowering as the full opening of the petals to expose stamens and pistil. Multiflowering plants were considered flowering when first florets bloomed. Hulbert (1963) and Leopold and Jones (1947) reported flowering of trees when first pollen was shed as noted in Table 1. Stevens (1956) reported flowering when first pollen was shed for all plants. White (1979) reported flowering of forbs and shrubs when $10 \%$ of the plants within the study area had at least one flower. Criddle (1927) did not state how he determined first flowering.

Mean flowering date and summation of degree days or degree days times daylength factor at each location were restricted to the following 5-year periods: 1950 through 1954 for Swift Current, Fargo, and Manhattan, 1910 through 1914 for Treesbank, 1967 through 1971 for Sidney, 1941 through 1945 for Sauk and Dane, and 1891 through 1895 for Wauseon. It was assumed that any 5year period within the data sets should accurately estimate the mean flowering date of a species. Too many species would have been eliminated if a longer period had been chosen. Linear and quadratic polynomial regressions were used to plot flowering dates of plants at Treesbank versus 7 other locations. Treesbank was chosen as the common location to compare all others to because its had flowering dates of the largest number of species that were common to all locations. If any other location had been used it would have decreased the number of species available for comparison. Each regression was significant at $P<0.05$ level.

Daily maximum and minimum air temperatures from first of December through last of September for the 5-year period selected for Swift Current airport, Brandon (closest weather station to Treesbank), Sidney, Fargo, Wisconsin Dell for Sauk, Madison for Dane, Wauseon, and Manhattan (town) were used to calculate degree days or degree days times daylength factor. Degree hours were accumulated every 0.1 hour from sunrise to sunset then divided by 10 and by daylength to put it on a daily bases. Air temperature every 0.1 hour was determined from maximum and minimum temperatures by de Wit (1978) method. Baker et al. (1988) found that the de Wit method was most accurate in estimating hourly air temperatures of the 3 methods tested. Daily sunrise and sunset at each location was calculated with a HewlettPackard time-shared BASIC computer program (36180 rev. A 3/72).

The method reported by Lindsey and Newman (1956) was used to determine which threshold temperature from -6 to $10^{\circ} \mathrm{C}$ (at $2^{\circ}$ $\mathrm{C}$ interval) was optimum in predicting flowering dates at 5 locations (Sidney, Sauk, Dane, Wauseon, and Manhattan) where individual yearly flowering dates were available. The optimum threshold temperature was at the inflection point when the coefficient of variations were plotted for the various threshold temperatures (Lindsey and Newman 1956). A 4-year period was used at Sidney, Sauk, and Dane while a 5-year period was used at Wauseon and Manhattan.

The average number of degree days or degree days times daylength factor over 5 years was than calculated for each location for each day of the year. The mean flowering date for each species at each location was used to calculate the average (over 5 years) degree days or degree days times daylength factor that had been accumulated when each species flowered at each location.

The accuracy of each method in predicting flowering dates was evaluated by 2 methods. The first method determined accuracy by plotting the various mean (averaged over 5 years) degree days or degree days times daylength factor calculated for each species at each of the 7 locations against that calculated for Treesbank. A method was considered accurate if the variability around the linear model was small enough that I could accept the hypothesis of a 1 to 1 relationship of degree days or degree days times daylength factor required for each species to flower from the earliest to the latest flowering species. Because of the nature of the data sets from the 8 locations almost all of the usable information was required to develop the model, consequently validation will come from use of the model in future research.

The second method of determining accuracy was the standard deviation in days between mean flowering date and predicted flowering date. The variation of degree days or degree days times daylength factor between locations was not used to determine the accuracy of each method because of the large difference in the size of numbers between methods. The size of units also varied depending upon threshold temperature and weight given to daylength.

A common base unit was needed to compare how well each method accounted for variation in flowering dates between locations. Therefore, a normalizing procedure was used to convert the various methods of accumulated degree days or degree days times daylength factor to an appropriate calendar date for each species at each location. The mean unit over locations was used to calculate the calendar date that a method would predict flowering of each species at each location. The difference between the actual flowering date and predicted flowering date was used to calculate standard deviation by location. Thus the various methods of accumulating degree days or degree days times daylength factor were compared in plus or minus so many days. White (1979) used a similar method to compare the accuracy of various methods in predicting the flowering date of 53 species near Sidney, Mont., over a 4-year period.

\section{Results and Discussion}

There was a straight line relationship between species 
Table 1. List of 130 plant species (alternate name in parenthesis), mean flowering date (month/day), years of record used to determine the best method to predict flowering dates at 8 location in central North America.

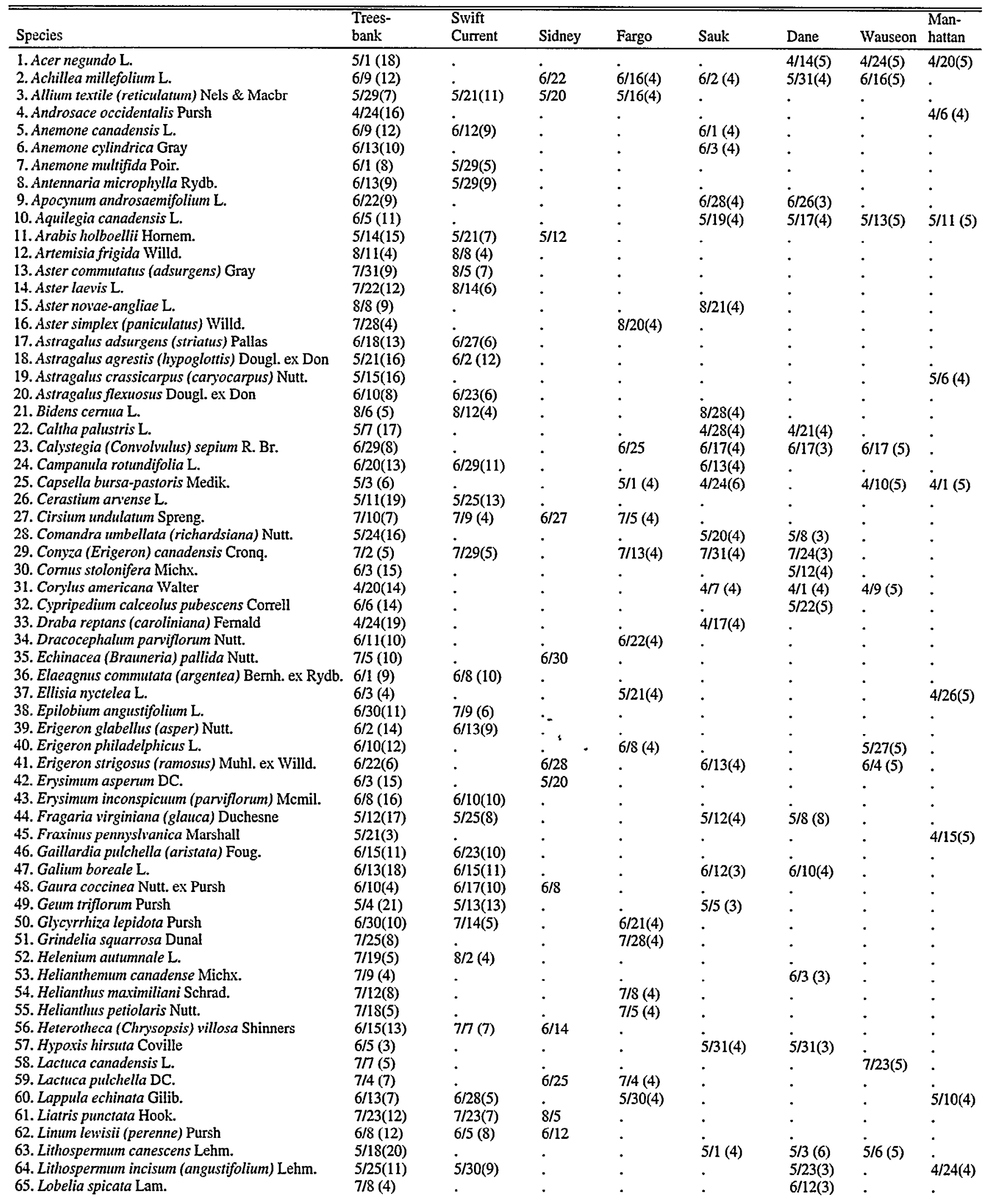


Table 1. Continued.

\begin{tabular}{|c|c|c|c|c|c|c|c|c|}
\hline Species & $\begin{array}{l}\text { Trees- } \\
\text { bank }\end{array}$ & $\begin{array}{l}\text { Swift } \\
\text { Current } \\
\end{array}$ & Sidney & Fargo & Sauk & Dane & Wauseon & $\begin{array}{l}\text { Man- } \\
\text { hattan }\end{array}$ \\
\hline 66. Lygodesmia juncea Don ex Hook. & $7 / 8(4)$ & $7 / 11(6)$ & $7 / 7$ & $7 / 3(3)$ & - & - & . & . \\
\hline 67. Lysimachia (Steironema) ciliata L. & $6 / 27(9)$ & $7 / 16(4)$ & . & . & . & • & - & $\cdot$ \\
\hline 68. Maianthemum canadense (interius) Desf. & $6 / 5(9)$ & . & . & - & $6 / 3(4)$ & - & - & - \\
\hline 69. Mirabilis (Oxybaphus) nyctaginea Macmil. & $6 / 18(5)$ & - & • & $6 / 17(4)$ & - & - & - & $5 / 16(5)$ \\
\hline 70. Oenothera biennis (strigosa) L. & $6 / 30(9)$ & $7 / 10(4)$ & - & $7 / 13(4)$ & $7 / 5(4)$ & - & & \\
\hline 71. Oenothera nutrallii (pallida) Sweet & $7 / 4(8)$ & $7 / 24(4)$ & . & $6 / 22(4)$ & - & - & - & - \\
\hline 72. Orthocarpus luteus Nutt. & $7 / 7(10)$ & $7 / 27(6)$ & . & $\cdot$ & . & - & . & . \\
\hline 73. Oxalis stricta $\mathrm{L}$. & $6 / 6(5)$ & . & $\dot{0}$ & $6 / 9(4)$ & $5 / 22(4)$ & $5 / 24(4)$ & $6 / 8(5)$ & $5 / 7(5)$ \\
\hline 74. Oxytropis lambertii Pursh & $6 / 7(12)$ & - & $5 / 22$ & $6 / 3(4)$ & - & . & - & - \\
\hline 75. Penstemon albidus Nutt. & $6 / 7(15)$ & $6 / 9(11)$ & $6 / 3$ & . & - & $\cdot$ & - & - \\
\hline 76. Penstemon gracilis Nutt. & $6 / 17(10)$ & $6 / 26(10)$ & . & • & $6 / 4(4)$ & - & • & - \\
\hline 77. Petalostemon candidus Michx. & $6 / 29(9)$ & $7 / 12(6)$ & ; & . & $7 / 12(4)$ & - & - & . \\
\hline 78. Petalostemon purpureus Vent. & $7 / 5(8)$ & $7 / 21(8)$ & $7 / 14$ & • & $7 / 12(4)$ & - & - & - \\
\hline 79. Phlox hoodii Richards. & $5 / 3(5)$ & $4 / 30(13)$ & $4 / 26$ & - & . & - & . & - \\
\hline 80. Plantago major $\mathrm{L}$. & $6 / 23(4)$ & - $\quad$ & . & $6 / 23(4)$ & . & . & $7 / 2(5)$ & - \\
\hline S1. Polygonatum commutalum (canaliculatum) Diet & r. $6 / 20(11)$ & - & . & . & - & - & $6 / 12(5)$ & - \\
\hline 82. Populus deltoides Bartram (pollen) & $5 / 11(4)$ & - & . & - & - & $4 / 13(4)$ & $4 / 30(5)$ & - \\
\hline 83. Populus tremuloides Loeve \& Loeve (pollen) & $4 / 19(21)$ & - & . & . & $4 / 10(6)$ & $4 / 10(6)$ & $4 / 3(5)$ & . \\
\hline 84. Poremilla anserina $\mathrm{L}$. & $6 / 1(18)$ & $5 / 29(7)$ & . & . & . & • & . & - \\
\hline 85. Potentilla arguta Pursh & $6 / 18(8)$ & $7 / 2(7)$ & . & . & $6 / 7(4)$ & - & • & - \\
\hline 86. Potentilla concinna Richards. & $5 / 1(13)$ & $5 / 7(12)$ & . & & . & . & - & - \\
\hline 87. Potentilla norvegica (monspeliensis) L. & $6 / 18(6)$ & $7 / 12(3)$ & ; & $6 / 19(4)$ & - & - & • & . \\
\hline 8S. Potentilla pensylvanica (strigosa) L. & $6 / 18(10)$ & $7 / 7(5)$ & $6 / 23$ & . & . & . & . & . \\
\hline 89. Prumus pensylvanica L.F. & $5 / 17(20)$ & . & . & . & $5 / 5(4)$ & $5 / 1(4)$ & - & . \\
\hline 90. Prunus pumila (besseyi) L. & $5 / 17(17)$ & . & . & . & $5 / 3(4)$ & . & - & . \\
\hline 91. Prunus virginiana L. & $5 / 28(16)$ & - & . & . & $5 / 3(4)$ & $5 / 8(4)$ & - & $5 / 11(4)$ \\
\hline 92. Psaralea argophylla Pursh & $7 / 2(7)$ & $7 / 13(8)$ & $7 / 4$ & $6 / 29(4)$ & . & - & • & - \\
\hline 93. Psoralea esculenta Pursh & $6 / 19(10)$ & . & $6 / 13$ & . & . & . & . & - \\
\hline 94. Pulsatilla patens (wolfgangiana) Mill. & $4 / 13(21)$ & $4 / 20(13)$ & . & . & $4 / 7(4)$ & $4 / 10(8)$ & . & - \\
\hline 95. Quercus macrocarpa Michx. & $5 / 27(19)$ & . & • & . & . & . & $5 / 15(5)$ & $4 / 30(5)$ \\
\hline 96. Ranunculus rhomboideus Goldie & $4 / 20(19)$ & $5 / 3(13)$ & . & - & - & - & . & . \\
\hline 97. Ranunculus sceleratus L. & $6 / 3(15)$ & $\dot{0}$ & $\dot{0}$ & $5 / 30(4)$ & . & . & - & . \\
\hline 98. Ratibida columnifera Wooton \& Standl. & $7 / 2(9)$ & $7 / 13(8)$ & $7 / 7$ & $7 / 4(4)$ & - & . & . & . \\
\hline 99. Rosa blanda var. hispida Ait. & $6 / 13(15)$ & . & - & . & $6 / 2(4)$ & $6 / 1(4)$ & . & . \\
\hline 100. Rudbeckia laciniata L. & $7 / 13(6)$ & . & . & $7 / 26(4)$ & $7 / 19(4)$ & . & . & - \\
\hline 101. Rudbeckia serotina hirta Nutt. non Sweet & $6 / 28(9)$ & - & . & $6 / 19(3)$ & $6 / 22(4)$ & $6 / 17(4)$ & $7 / 3(5)$ & . \\
\hline 102. Rumex venosus Pursh & $5 / 26(3)$ & . & - & - & $\cdot$ & $\cdot$ & . & $5 / 2(5)$ \\
\hline 103. Sagittaria latifolia Willd. & $7 / 14(4)$ & • & . & . & $7 / 27(3)$ & . & . & . \\
\hline 104. Salix discolor Muhl. & $4 / 19(20)$ & - & . & . & . & $4 / 6(7)$ & . & \\
\hline 105. Senecio cantus Hook. & $6 / 4(7)$ & $6 / 9(8)$ & . & - & - & $\cdot$ & . & . \\
\hline 106. Senecia plattensis Nutt. & $6 / 4(15)$ & . & . & - & . & . & . & $5 / 14(5)$ \\
\hline 107. Silene antirrhina L. & $6 / 21(10)$ & . & . & $6 / 20(3)$ & . & - & . & - \\
\hline 108. Silene noctiflora $\mathrm{L}$. & $6 / 24(4)$ & . & . & $6 / 22(3)$ & . & . & - & . \\
\hline 109. Sisyrinchium angustifolium Mill. & $5 / 25(11)$ & $6 / 8(11)$ & . & $\cdot$ & - & . & . & . \\
\hline 110. Smilacina stellata Desf. & $5 / 26(16)$ & $5 / 30(7)$ & . & - & $5 / 14(4)$ & $5 / 8(5)$ & . & $4 / 30(5)$ \\
\hline 111. Solidago canadensis L. & $7 / 17(11)$ & . & - & $8 / 8(4)$ & . & - & . & • \\
\hline 112. Solidago missouriensis Nutt. & $7 / 3(5)$ & $7 / 20(5)$ & $7 / 30$ & : & : & . & - & - \\
\hline 113. Solidago rigida $\mathrm{L}$. & $7 / 20(13)$ & $7 / 20(4)$ & - & $8 / 10(4)$ & $8 / 25(4)$ & $8 / 15(3)$ & $\cdot$ & - \\
\hline 114. Sphaeralcea (Malvastrum) coccinea Rydb. & $6 / 7(4)$ & $6 / 16(13)$ & $6 / 9$ & - & ; & - & - & - \\
\hline 115. Spiraea alba (salicifolia) Du Roi & $6 / 28(10)$ & - & - & $\dot{0}$ & $7 / 8(6)$ & • & - & - \\
\hline 116. Stachys palustris L. & $6 / 29(8)$ & $7 / 17(5)$ & • & $7 / 1(4)$ & . & · & - & - \\
\hline 117. Stellaria longipes Goldie & $5 / 30(7)$ & $6 / 12(6)$ & $\dot{z}$ & - & . & . & - & - \\
\hline 118. Symphoricarpos occidentalis Hook. & $6 / 25(10)$ & $7 / 3(9)$ & $7 / 13$ & $6 / 26(4)$ & . & - & $\cdot$ & - \\
\hline 119. Tararacum officinale Weber & $5 / 19(8)$ & $4 / 26(10)$ & $5 / 10$ & $5 / 9(4)$ & • & $4 / 17(5)$ & $4 / 26(5)$ & $3 / 17(4)$ \\
\hline 120. Thermopsis rhombifolia Nutt. ex Richards. & $6 / 11(4)$ & $5 / 10(13)$ & - & - & . & · & - & . \\
\hline 121. Toxicodendron (Rhus) radicans Kuntze & $6 / 16(8)$ & . & - & $6 / 17(4)$ & $6 / 12(4)$ & . & $6 / 19(5)$ & . \\
\hline 122. Ulmus americana L. (pollen) & $4 / 28(14)$ & . & - & - & $4 / 14(4)$ & $4 / 5(4)$ & $4 / 8(5)$ & $3 / 9(5)$ \\
\hline 123. Viburnum lentago L. & $6 / 9(12)$ & - & - & • & $5 / 26(5)$ & - & · & . \\
\hline 124. Viburmum opulus (trilobum) L. & $6 / 9(11)$ & • & - & : & · & - & $5 / 27(5)$ & . \\
\hline 125. Vicia americana Muhl. ex Willd. & $6 / 4(16)$ & - & - & $5 / 31(4)$ & • & - & · & - \\
\hline 126. Vicia sparsifolia Nutt. ex Torr. \& Gray & $5 / 26(9)$ & $6 / 1(10)$ & - & $6 / 1(4)$ & · & - & . & . \\
\hline 127. Viola canadensis $\mathrm{L}$. & $5 / 17(16)$ & - & $\cdot$ & - & $\cdot$ & . & $5 / 10(5)$ & . \\
\hline 128. Viola conspersa Reichenb. & $5 / 6(21)$ & . & - & - & - & - & $5 / 4(5)$ & - \\
\hline 129. Viola pedatifida Don & $5 / 21(15)$ & $6 / 1(3)$ & - & - & $\cdot$ & - & $5 / 1(5)$ & - \\
\hline 130. Zizia aptera (cordata) Fernald & $5 / 29(9)$ & $6 / 4(10)$ & $\cdot$ & . & . & . & . & . \\
\hline
\end{tabular}


flowered at Swift Current, Sidney, and Manhattan compared to when they flowered at Treesbank (Fig. 1). However, the relationship of flowering date at Fargo, Sauk, and Wauseon with those at Treesbank was curvilinear. The coefficient of determination $\left(\mathrm{r}^{2}\right)$ of flowering dates at Treesbank versus the other 7 locations was the lowest at Manhattan (0.84) and ranged from 0.90 to 0.96 at the other locations. These data showed that plants flowering in late June flowered at the same time regardless of latitude. Plants flowering at the other 6 locations before late June were earlier than those at Treesbank and those flowering after late June were later than those flowering at Treesbank. This relationship is similar to that predicted by Hopkins' Law (Hopkins 1938).

Flowering dates of 10 of the 130 species deviated more than 15 days from the regression line for a given location. The mean flowering date of only $3,2,0,0,3,0$, and 4 species at Swift Current, Sidney, Fargo, Sauk, Dane, Wauseon, and Manhattan, respectively, deviated more than 15 days. These deviations could have been caused by genotypes, different responses to daylength, and temperature at the various locations. These 10 species could have also been misnamed or subspecies.

Taraxacum officinale deviated from the regression line 20 to 30 days at Swift Current, Dane, and Manhattan. Because of this deviation Taraxacum officinale would not be a good index species for predicting development of other species. Later flower- ing species such as Cirsium undulatum at Sidney, Helianthemum canadense at Dane, Lobelia spicata at Dane, and Solidago missouriensis at Sidney all flowered more than 18 to 35 days off the regression line at one location. The early flowering species that deviated significantly from the regression line were Acer negundo at Manhattan, Androsace occidentalis at Manhattan, Antennaria microphylla at Swift Current, Astragalus crassicarpus at Manhattan, and Thermopsis rhombifolia at Swift Current. The remaining 124 species present at 2 or more locations were used to test the accuracy of various methods to predict flowering dates.

I tested 49, 87, 23, 18, and 37 species at Sidney, Sauk, Dane, Wauseon, and Manhattan to determine the optimum threshold temperature to predict flowering date with degree days by Lindsey and Newman (1956) method. Species at Sidney and Manhattan were divided into early and late flowering groups. Species at Sauk were divided into early, middle, and late flowering groups. Species at Dane and Wauseon were left in one group at each location. This method found that the optimum threshold temperature was $2^{\circ} \mathrm{C}$ for all locations except Sidney. Sidney's optimum threshold temperature was $3^{\circ} \mathrm{C}$ for both the early and late flowering groups. The optimum threshold temperature for both the early and late flowering groups at Manhattan was $2^{\circ} \mathrm{C}$. The optimum threshold temperature for all 3 groups at Sauk was
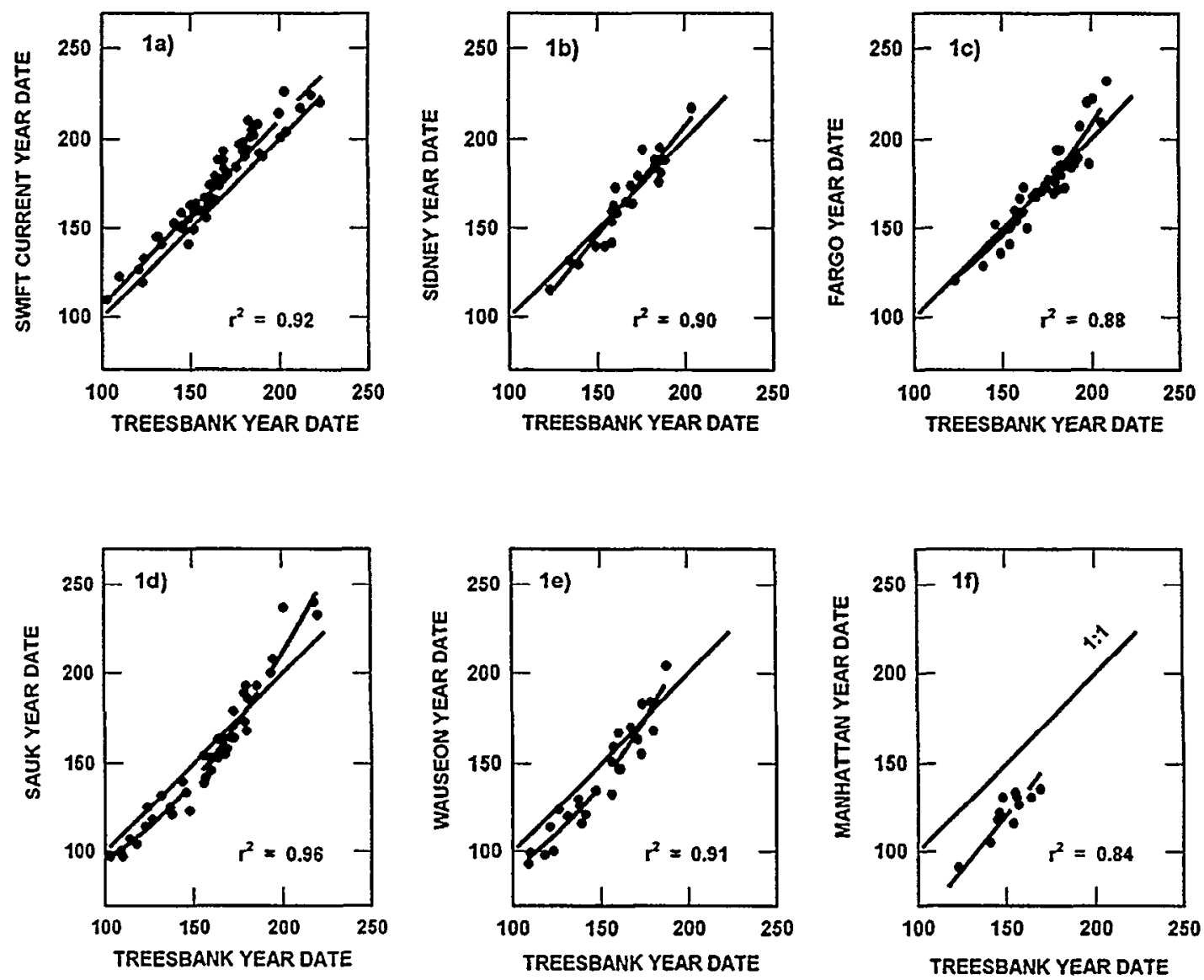

Fig. 1. Relationship of year date (days from 1st of Jan.) that plants flowered at Treesbank, Manitoba versus Swift Current, Saskatchewan; Sidney, Mont.; Fargo, N. D.; Sauk Co., Wisc.; Wauseon, Ohio; and Manhattan, Kans. 
Table 2. Accuracy of degree days, degree days times daylength, and degree days times daylength factor (all threshold $2^{\circ} \mathrm{C}$ ) in predicting the flowering date of 14 to 61 species at Treesbank versus 7 other locations.

\begin{tabular}{|c|c|c|c|c|}
\hline $\begin{array}{l}\text { Location } \\
\text { species }\end{array}$ & Equation & Degree days & $\begin{array}{l}\text { Degree days } \\
\text { times } \\
\text { daylength }\end{array}$ & $\begin{array}{l}\text { Degree days } \\
\text { times day- } \\
\text { length factor }\end{array}$ \\
\hline $\begin{array}{l}\text { Swift } \\
\text { Current } \\
n=61\end{array}$ & $\begin{array}{l}\text { Intercept } \\
\text { Slope } \\
r^{2} \\
\text { Sd, days }\end{array}$ & $\begin{array}{l}31 \\
0.93 \\
0.92 \\
5.3\end{array}$ & $\begin{array}{l}604 \\
0.93 \\
0.92 \\
4.0\end{array}$ & $\begin{array}{l}1926 \\
0.95 \\
0.92 \\
0.1\end{array}$ \\
\hline $\begin{array}{l}\text { Sidney } \\
\mathrm{n}=23\end{array}$ & $\begin{array}{l}\text { Intercept } \\
\text { Slope } \\
r^{2} \\
\text { Sd, days }\end{array}$ & $\begin{array}{l}-36 \\
1.24 \\
0.88 \\
-6.1\end{array}$ & $\begin{array}{l}-648 \\
1.21 \\
0.88 \\
-4.8\end{array}$ & $\begin{array}{l}-123 \\
1.05 \\
0.87 \\
-1.7\end{array}$ \\
\hline $\begin{array}{l}\text { Fargo } \\
n=40\end{array}$ & $\begin{array}{l}\text { Intercept } \\
\text { Slope } \\
\mathbf{r}^{3} \\
\text { Sd, days }\end{array}$ & $\begin{array}{l}-250 \\
1.32 \\
0.87 \\
2.0\end{array}$ & $\begin{array}{l}-3265 \\
1.27 \\
0.87 \\
1.3\end{array}$ & $\begin{array}{l}-2494 \\
1.05 \\
0.88 \\
2.4\end{array}$ \\
\hline $\begin{array}{l}\text { Sauk } \\
\mathrm{n}=39\end{array}$ & $\begin{array}{l}\text { Intercept } \\
\text { Slope } \\
r^{2} \\
\text { Sd, days }\end{array}$ & $\begin{array}{l}-105 \\
1.52 \\
0.93 \\
-6.1\end{array}$ & $\begin{array}{l}-1672 \\
1.43 \\
0.93 \\
-4.5\end{array}$ & $\begin{array}{l}-1353 \\
1.10 \\
0.94 \\
-0.1\end{array}$ \\
\hline $\begin{array}{l}\text { Dane } \\
n=28\end{array}$ & $\begin{array}{l}\text { Intercept } \\
\text { Slope } \\
r^{2} \\
\text { Sd, days }\end{array}$ & $\begin{array}{l}-141 \\
1.41 \\
0.90 \\
2.9\end{array}$ & $\begin{array}{l}-2037 \\
1.31 \\
0.90 \\
3.7\end{array}$ & $\begin{array}{l}-1626 \\
0.98 \\
0.90 \\
6.0\end{array}$ \\
\hline $\begin{array}{l}\text { Wauseon } \\
n=25\end{array}$ & $\begin{array}{l}\text { Intercept } \\
\text { Slope } \\
\mathrm{r}^{2} \\
\text { Sd, days }\end{array}$ & $\begin{array}{l}-4 \\
1.52 \\
0.89 \\
-9.8\end{array}$ & $\begin{array}{l}-462 \\
1.41 \\
0.88 \\
-6.6\end{array}$ & $\begin{array}{l}224 \\
1.02 \\
0.88 \\
-1.8\end{array}$ \\
\hline $\begin{array}{l}\text { Manhattan } \\
\mathrm{n}=14\end{array}$ & $\begin{array}{l}\text { Intcrecpt } \\
\text { Slope } \\
\Gamma^{2} \\
\text { Sd, days }\end{array}$ & $\begin{array}{l}255 \\
1.19 \\
0.79 \\
-18.4\end{array}$ & $\begin{array}{l}2690 \\
1.00 \\
0.79 \\
-10.2\end{array}$ & $\begin{array}{l}3608 \\
0.61 \\
0.75 \\
-1.1\end{array}$ \\
\hline
\end{tabular}

$2^{\circ} \mathrm{C}$. Therefore $2^{\circ} \mathrm{C}$ was used as the threshold temperature for all species. White (1979) also found by a different method that $2^{\circ}$ $\mathrm{C}$ was the optimum threshold temperature for early flowering species and $4^{\circ} \mathrm{C}$ for late flowering species.

The degree days (threshold $2^{\circ} \mathrm{C}$ ) predicted flowering dates with a standard deviation of 2 to 18 days at the various locations (Table 2). Regression analysis showed that slope of accumulated degree days of when each species flowered varied from 0.92 to 1.52 depending upon the location.

Degree days (threshold $2^{\circ} \mathrm{C}$ ) times daylength as suggested by Nuttonson (1955) was better than the degree days in predicting flowering dates. It's standard deviation was 1 to 8 days better than degree day only depending upon the location. Again there was not a 1 to 1 relationship between accumulated degree days times daylength of when each species flowered at Treesbank and any of the other 7 locations. Slopes ranged from 0.93 to 1.43 (Table 2).

The degree days (threshold $2^{\circ} \mathrm{C}$ ) times daylength factor $(1 /(0.259-0.0140 *$ daylength $)$ was by far the best method to predict flowering dates of 124 species divided among 8 locations. This daylength factor slightly discounted daylength below 13 hours and greatly increased its weight for every hour over 13 hours (Fig. 2). This method had a standard deviation of 3 to 9
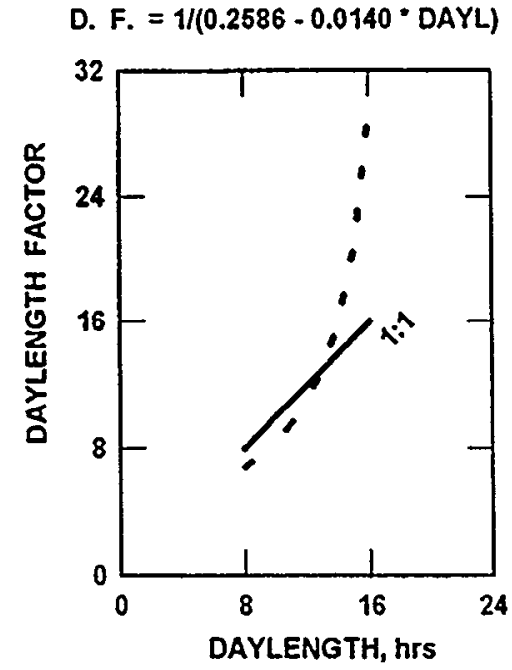

Fig. 2. Equation used to factor daylength (D. F.) to predict flowering of 124 plants divided among 8 locations in central North America.

days less than degree days times daylength at 5 of the 7 locations (Table 2). It had a standard deviation of 0 to 17 days better than degree days only at 6 of 7 locations. Regression analysis showed that slope of accumulated degree days times daylength factor of when each species flowered was nearly one at 6 of 7 locations thus the variability was small enough that $I$ could accept the hypothesis of a 1 to 1 relationship of degree days times daylength factor accumulated at Treesbank versus any of the other locations (Fig. 3).

During the process of determining how to adjust daylength to predict flowering it became apparent that degree days times daylength factor had to be accumulated from the first of December in order to predict flowering dates at Manhattan. Accumulation of degree days or thermal units from the first of March worked well at Sidney, Mont. (White 1979). However, even accumulation of degree days times daylength factor from the first of January or later caused large errors in predicting flowering dates at Manhattan.

Degree days times daylength factor need to be calculated at least every hour from sunrise to sunset to accurately accumulate thermal units. Lindsey (1963) found that using only maximum and minimum temperatures with the degree days caused an 8 to $15 \%$ error in calculating degree days.

\section{Conclusions}

The degree days times daylength factor accurately predicted flowering dates of 124 species among 8 locations ranging from 39 to $50^{\circ} \mathrm{N}$ latitude and 84 to $108^{\circ} \mathrm{W}$ longitude. The degree days and degree days times daylength could not be used to predict flowering dates of plants at widely ranging latitudes. Each hour of daylength above 13 hours had a larger effect on flowering than each hour under 13 hours. This accounts for why crops planted at different times of the year did not develop or mature with the same number of degree days. There was a 1:1 relationship between degree days times daylength factor required for plants to 

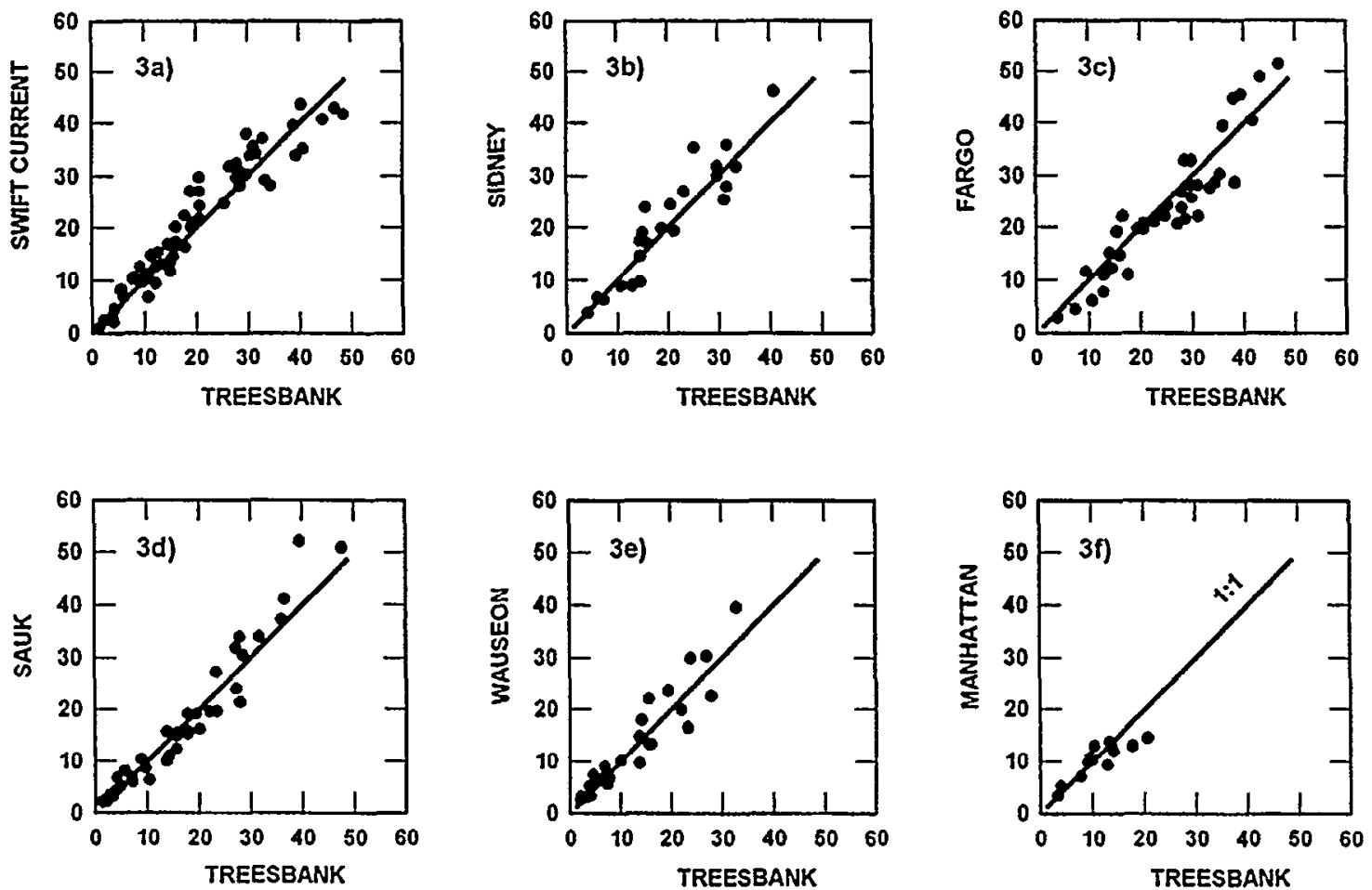

Fig. 3. Relationship of degree days times daylength factor (1,000s) accumulated when plants flowered at Treesbank, Manitoba versus Swift Current, Saskatchewan; Sidney, Mont.; Fargo, N.D.; Sauk Co., Wisc.; Wauseon, Ohio; and Manhattan, Kans.

flower at Treesbank versus 7 other locations with a wide range of latitude. This method accounted for why plants that flower in late June flower at all latitudes at the same time. It also accounted for why plants that flower before late June flower earlier at southern latitudes and why plants that flower after late June flower later at southern latitudes when compared to those at a northern location.

\section{Literature Cited}

Baker, C.K., J.N. Gallagher, and J.L. Monteith. 1980. Daylength change and leaf appearance in winter wheat. Plant Cell Environ. 3:285-287.

Baker, J.M., D.C. Reicosky, and D.G. Baker. 1988. Estimating the time dependence of air temperature using daily maxima and minima: A comparison of three methods. J. Atmos. and Oceanic Tech. 5:736-742.

Budd, A.C., and J.B. Campbell. 1959. Flowering sequence of a local flora. J. Range Manage. 12:127-132.

Caprio, J.M. 1967. Phenological patterns and their use as climatic indicators. p. 17-43. In: Ground Level Climatology. Amer. Assoc. Adv. Sci. Pub. No. 86, Washington, D.C.

Criddle, N. 1927. A calendar of flowers. Can. Field Nat. 41:48-55.

Holmes, R.M., and G.W. Robertson, 1959. Heat units and crop growth. Can. Dep. Agr. Pub. 1042, 31 pp.

Hopkins, A.D. 1938. Bioclimatics-A science of life and climate relations. USDA Misc. Pub. 280, U.S. Gov. Print. Office, Washington, D.C., 188 pp.

Hopp, R.J., and B.O. Blair. 1973. Plant phenology in eastern and central North America. I. Development of networks and preliminary results. Vermont Agr. Exp. Sta. Bull. 677, 21 pp.

Hulbert, L.C. 1963. Gates' phenological records of 132 plants at Manhattan, Kansas, 1926-1955. Trans. Kans. Acad. Sci. 66:82-106.

Leopold, A., and S.E. Jones. 1947. A phenological record for Sauk and Dane counties, Wisconsin, 1935-1945. Ecol. Monogr. 17:81-122.

Lindsey, A.A. 1963. Accuracy of duration temperature summing and its use for Prunus serrulara. Ecol. 44:149-151.

Lindsey, A.A., and J.E. Newman. 1956. Use of official weather data in spring time--Temperature analysis of an Indiana phenological record. Ecol. 37:812-823.

Madariaga, F.J., and J.E. Knott. 1951. Temperature summations in relation to lettuce growth. Proc. Amer. Soc. Hort. Sci. 58:147-152.

Magoon, C.A., and C.W. Culpepper. 1932. Response of sweet com to varying temperatures from time of planting to canning maturity. USDA Tech. Bull. 312,40 pp.

McMaster, G.S., and D.E. Smika. 1992. Estimation and evaluation of winter wheat phenology in the central Great Plains. Agr. For. Meteorol. 43:1-18.

McMaster, G.S., B. Klepper, R.W. Rickman, W.W. Wilhelm, and W.O. Willis, 1991. Simulation of shoot vegetative development and growth of unstressed winter wheat. Ecological Modelling 53:189-204.

Moorman, G.W., J.L. Rosenberger, and L.A. Gladstone. 1990. Comparison of two air temperature based models for predicting phenophase occurrence in Persian lilacs (Syringa chinensis) cultivar Red Rothomagensis. Can. J. Bot. 68:1113-1116.

Nuttonson, M.Y. 1955. Wheat-climate relationships and the use of phenology in ascertaining the thermal and photothermal requirements of wheat. American Institute of Crop Ecology, Washington, D.C., 388 pp.

Robertson, G.W. 1953. Some agro-meteorological problems in Canada. Royal Meteorol. Soc., (Canadian Branch) 4:1-21.

Robertson, G.W. 1968. A biometeorological time scale for cereal crops involving day and night temperatures and photoperiod. Int. J. Biometeorol. 12:191-223.

Smith, J.W. 1915. II. Phenological dates and meteorological data recorded by Thomas Mikesell between 1873 and 1912 at Wauseon, Ohio. U.S. Weather Bur. Monthly Weather Rev. Suppl. No. 2, pp. 23-93.

Stevens, O.A. 1956. Flowering dates of weeds in North Dakota. North Dakota Agr. Exp. Sta. Bull. 18:209-213.

White, L.M. 1979. Relationship between meteorological measurements and flowering of index species to flowering of 53 plant species. Agr. Meteorol. 20:189-204.

Wit, C.T. de 1978. Simulation of assimilation, respiration, and transpiration of crops. Pudoc, Wageningen, $148 \mathrm{pp}$.

Wright, D., and LL.G. Hughes. 1987. Relationships between time, temperature, daylength and development in spring barley. J. Agr. Sci. (Camb.) 109:365-373. 